\title{
Studying the Hierarchical Interrelationships amongst the Success Factors for Commerce of Indian Inner Wear Industry
}

\author{
Lakshay Aggarwal \\ Sociobuddy Technologies Private \\ Limited \\ Delhi, India
}

\author{
Lokik Aggarwal \\ Recventures Education Services \\ Private Limited \\ Delhi, India
}

\author{
Remica Aggarwal \\ Recventures Education Services \\ Private Limited \\ Delhi, India
}

\begin{abstract}
Present study focuses on identifying various challenges or barriers as well as success factors for commerce of Indian inner wear industry. After exploring various challenges through extensive literature review and internet search, the identified factors are further studied for the possible hierarchical relationships amongst them using Interpretive Structural Modelling methodology.
\end{abstract}

\section{Keywords}

ISM methodology, Small medium enterprises, inner wear industry, lingerie industry

\section{INTRODUCTION}

Indian apparel industry is the second largest retail category (behind food and groceries), representing approximately $10 \%$ of the total market. Indian apparel sales are expected to reach an estimated INR 4700 billion by 2020 on the back of the faster growth in the organised apparel segment representing a CAGR of 10.6. The women's segment that has historically been smaller in size compared to the men's segment is expected to grow at a faster pace i.e. at a CAGR of $15 \%$ over 2010-2020 as compared to $10 \%$ CAGR in the men's segment.

The innerwear category ${ }^{1,2}$ has broadened from being a basic requirement to designer wear with emphasis on styling and comfort. This has also given the brands an opportunity to play with designs, cuts, colours, styles, etc. The Indian innerwear market is certainly one of the most unique markets amongst the major markets of the world today. A distinctive shift from price sensitivity to brand sensitivity and preference for bold colors and innovative designs are two key trends to have emerged in this segment. Provided the positive macro and demographic fundamentals, the innerwear market has a favorable demand growth outlook over the medium-to-long term . Not only are international brands trying to grab a pie in the market share, but domestic and national brands too are pulling up their socks, or rather 'underpants', to tap this market by offering stylish and trendy innerwear. Improving Indian demographics and increased preference for proper fits, sizes, etc. lend credence to the growth of organized players in the Indian innerwear market. Organized players (including Page Industries, Lovable Lingerie and Rupa \& Company, among listed players) are well poised to capture this growth. The lingerie market in India can be classified in luxury, premium, mid-market and mass market segment. The major share of lingerie market is held by the mid-market segment. The premium and the luxury markets are growing at double the rate in comparison to the middle segment. The innerwear market currently valued at 14,300 crore (in 2011) is expected to grow to 43,700 crore by 2020 , growing at a CAGR of $13.2 \%$, outpacing the growth of the overall apparel market.
The women's innerwear segment is likely to touch 30,000 crore from the current INR 8,500 crore. On the other hand, the men's innerwear segment is likely to grow from 5,800 crore in 2010 to INR 13,700 crore in 2020. Apart from international brands like Hanes, Garfield, Voluptina and Scandale, Amazon.in has Indian brands such as Enamor, Lovable, Libertina, PrettySecrets, Floret, Heart2Heart and Soie on its platform.

Present paper is organized as follows . Section 2 presents the literature . Section 3 explains the ISM methodology . Section 4 applies the approach to both the scenarios. Section 5 provides the future directions and section 6 provides the managerial implications .

\section{LITERATURE REVIEW}

Change in women's perspective of intimate wear from a basic need to aspiration has changed the outlook of the lingerie or inner wear market. In response to increasing demand of intimate wear, market players are taking efforts to design intimate wear that satisfy quality, performance and comfort needs of consumer. Changing lifestyle and demographic dividend, rising awareness on hygiene and customization of product portfolios have boosted the intimate wear market. Up gradation in fabric used to manufacture intimate wear offers promising opportunities for market players. The higher income, along with higher discretionary spending, growing fashion orientation of consumers and product innovations by the innerwear market have turned innerwear from a traditionally utilitarian item to an essential fashion requirement. There are the common ones all new brands face, of course, like gaining traffic, increasing trust and standing out in a noisy market environment. New lingerie brands, however, face another hurdle: cracking into a space whose companies have high rates of customer retention. Research shows that in volume terms, women's lingerie segment holds a 52 percent share of the total innerwear market in India. In value terms, the women's lingerie segment holds a 66 percent share of the total innerwear market, thereby enjoying a higher Average Selling Price (ASP) as compared to the men's innerwear market. The following section focuses on various success factors to Indian inner wear industry .

\subsection{Success factors to Indian inner wear industry}

1. Retaining Customer Comfort (RCC) : A recent study of 1.3 million customer reviews [1] connected to fashion ecommerce products found that the words shoppers most commonly use have to do with fit, quality, size and comfort. And in no sector is this more true than lingerie. In the intimates industry, size really is personal -- it can vary from person to person, store to store and style to style. 
2. Proper advertising and capturing right influencers (PAC): A further aspect of the buying decision common to the lingerie industry is the plethora of dedicated online communities filled with participants eager to discuss the latest trends and brands in lingerie. In niche industries like these, therefore, it's important for up-and-coming lingerie brands to get their items into the hands of the right influencers and prove themselves.

3. Retaining trust and customer base (RTCB) : It's vital for new brands to focus on building trust and a solid reputation for great customer service. That effort starts from the moment customers land on your site and continues even after they've received their purchases. "As with all new brands, being responsive to customers is key [2].

\section{Social media awareness (SMA)}

Most Indian women are uncomfortable talking about lingerie openly. These days firms are therefore showcases lingeries or inner wear on social forum so that women can openly talk about their choices. Also these companies target to sell products which combines fashion with comfort at affordable rates targeted at Indian middle class.

\section{Strong online and offline omni-channel model (SOOM)} It is important to build a strong online and offline multidistribution strategy to ensure that their products are available wherever the customer is. The omni-channel model intends to provide a seamless shopping experience to customers. Brand outlets also help in getting more in-depth and qualitative feedback from customers.

\section{Expertise in logistics and supply chain management (ELSC)}

The backbone of this efficient network is technology with real-time decisions taken based on cost, time for average turnaround (TaT) and load time [1] .

\section{Expanding International Exposure (EIE):}

Recent years, India's popular online brands has been partnering with the biggest e-commerce websites of UAE and South East Asia. [1] . Currently estimated to be worth $\$ 3$ billion, India's lingerie market is wide open for multiple players.

\section{Media and awareness towards fashion and health} (M\&A): Media awareness towards fashion and health is driving the customers to keep more lingerie and inner wear in their wardrobe. Social media has helped in educating the consumer on benefits of good lingerie. Add on to it the rising youth population, rise of women spenders, increasing disposable income and a need for more solution based approach - and you have the perfect recipe for growth in segment.

9. Innovation and positive response (I\&PR): This is also the best time to innovate in product as the customer is far more demanding and aware as compared to past . Modern woman is increasingly working and stepping out of homes in diverse career options. These evolved women need more evolved wardrobe solutions and therefore need for multiple types of lingerie has become inevitable.

10. Growth in income level (GIL): This add on to their preference for recognizable brands and rapid growth of organized retail. Further this anticipate to increase the share of the organized lingerie market in the coming years.

11. The Online Game -- e commerce (ECOM): Ecommerce has been a game changer or rather a boon for this category. Main reason behind this is the awkwardness most women feel while going and buying lingerie from physical stores, manned by salesmen. It allows them to shop from their comfort zone and also allows them to browse through various styles and designs. This also comes with the easy returns and exchange policies provided. A lot many brands have gone ahead to have a tie-up with online giants like Flipkart, Myntra, etc., and many have even launched their own online portal.

12. Fabric and Technology (F\&T): For innerwear, cotton has been the king since time immemorial. But with advancements and inclination towards more trendy styles, there has been good growth for other fabrics including linen, nylon, etc. From 2017, the intimate wear sector has completely changed with much wider range of fabrics, including both natural and synthetic fibers range from satin, modal, silk, spandex, rayon, lace, mesh, polyamide, power net, etc. and even micro fibre. Stylewise also underwired, strapless, push-ups, bralettes, front open, convertible are few styles widely accepted and bought. From a basic brassier to one specially designed for a t-shirt, blouse, etc., the category has now expanded to luxurious velvet bras to sultry lace body suit, embroidered lingerie, camisoles, floral appliques, strappy bras, trendy sports bras and chemise. Additional detailing like charms, bows, contrast straps add a personalized element of style to every item of lingerie.

\section{Franchising (FR):}

Franchising is a tested business model in the retail sector globally, and the innerwear industry offers big opportunity to franchisors as well as the brands. Expansion of your business through franchising is an economic way to grow business and brand, without the additional pressure on your working capital. Another added advantage of franchising is the ability to reach tier -II and -III cities and bring local partners aboard who understand their market better than any company would.

\section{Positive dealing with the unorganized Indian} market (PDUM):

Trying to build a national brand in such a regionally fragmented and highly unorganised industry, where the segment is still at its nascent stage, is a challenge. But brands such as Jockey, Enamor, Clovia, and Amante provide strong competition with their price points, product portfolio, range, utility, and design.

\section{INTERPRETIVE STRUCTURAL MODELLING METHODOLOGY}

The modelling technique ISM was proposed by Warfield (1994). This technique stresses on creating a structured graph out of the set of unique interrelated variables. The technique works with the steps viz. First, identifying the relevant elements and establishing a contextual relationship amongst them . Next , an SSIM is developed to establish the led to relationship amongst the two variables $i \& j$. Thereafter, an initial reachability matrix and then a final reachability matrix is created which eventually lead to the development of the reachability set and antecedent set for each criterion . In every iteration a top level element is selected for which the reachability set and intersection sets are the same. Variables are further classified during the MICMAC analysis based on relative driving power and dependence power in to the categories like autonomous, dependent, driver and linkage.

\section{DEVELOPMENT OF ISM MODEL}

In this section, ISM model is developed for studying the interrelationships amongst various success factors for inner wear industry of India. Some fourteen factors are considered 
viz .

\subsection{Construction of Structural Self - Interaction Matrix (SSIM)}

This matrix gives the pair-wise relationship between two variables i.e. $i$ and $j$ based on VAXO. SSIM has been presented below in Fig 1.

\subsection{Construction of Initial reachability and final reachability matrix}

The SSIM has been converted in to a binary matrix called the initial reachability matrix shown in fig. 2 by substituting V, A, $\mathrm{X}, \mathrm{O}$ by 1 or 0 as per the case. After incorporating the transitivity, the final reachability matrix is shown below in the Fig 3.

\subsection{Level Partition}

From the final reachability matrix, reachability and final antecedent set for each factor are found. The elements for which the reachability and intersection sets are same are the top-level element in the ISM hierarchy. After the identification of top level element, it is separated out from the other elements and the process continues for next level of elements. Reachability set, antecedent set, intersection set along with different level for elements have been shown below in table 1 to table 7 .

Fig 1: Structural Self- Interaction Matrix

\begin{tabular}{|c|c|c|c|c|c|c|c|c|c|c|c|c|c|c|c|}
\hline & $\begin{array}{c}\text { Barr } \\
\text { iers }\end{array}$ & 1 & 2 & 3 & 4 & 5 & 6 & 7 & 8 & 9 & 10 & 11 & 12 & 13 & 14 \\
\hline & & RCC & PAC & RTCB & SMA & SOOM & ELSC & EIE & M\&A & I\&PR & GIL & ECOM & F\&T & FR & PDUM \\
\hline 1 & RCC & & A & V & A & A & O & V & A & V & A & A & V & A & X \\
\hline 2 & PAC & & & V & V & V & V & V & X & V & O & A & V & A & V \\
\hline 3 & RTCB & & & & O & A & A & A & O & A & O & A & A & A & A \\
\hline 4 & SMA & & & & & A & O & V & X & V & O & A & V & V & V \\
\hline 5 & SOOM & & & & & A & A & X & V & O & A & V & V & V \\
\hline 6 & ELSC & & & & & & & A & O & V & O & A & V & A & V \\
\hline 7 & EIE & & & & & & & O & V & O & A & V & X & A \\
\hline 8 & M\&A & & & & & & & & & V & A & A & V & O & O \\
\hline 9 & I\&PR & & & & & & & & & O & A & A & X & A \\
\hline 10 & GIL & & & & & & & & & & & A & V & V & O \\
\hline 11 & ECOM & & & & & & & & & & & V & O & V \\
\hline 12 & F\&T & & & & & & & & & & & & X & O \\
\hline 13 & FR & & & & & & & & & & & & & V \\
\hline 14 & PDUM & & & & & & & & & & & & \\
\hline
\end{tabular}

Fig 2: Initial reachability matrix

\begin{tabular}{|c|c|c|c|c|c|c|c|c|c|c|c|c|c|c|c|}
\hline & $\begin{array}{c}\text { Barr } \\
\text { iers }\end{array}$ & 1 & 2 & 3 & 4 & 5 & 6 & 7 & 8 & 9 & 10 & 11 & 12 & 13 & 14 \\
\hline & & RCC & PAC & RTCB & SMA & SOOM & ELSC & EIE & M\&A & I\&PR & GIL & ECOM & F\&T & FR & PDUM \\
\hline 1 & RCC & 1 & 0 & 1 & 0 & 0 & 0 & 1 & 0 & 1 & 0 & 0 & 1 & 0 & 1 \\
\hline 2 & PAC & 1 & 1 & 1 & 1 & 1 & 1 & 1 & 1 & 1 & 0 & 0 & 1 & 0 & 1 \\
\hline 3 & RTCB & 0 & 0 & 1 & 0 & 0 & 0 & 0 & 0 & 0 & 0 & 0 & 0 & 0 & 0 \\
\hline 4 & SMA & 1 & 0 & 0 & 1 & 0 & 0 & 1 & 1 & 1 & 0 & 0 & 1 & 1 & 1 \\
\hline 5 & SOOM & 1 & 0 & 1 & 1 & 1 & 0 & 0 & 1 & 1 & 0 & 0 & 1 & 1 & 1 \\
\hline 6 & ELSC & 0 & 0 & 1 & 0 & 0 & 1 & 1 & 0 & 1 & 0 & 0 & 1 & 0 & 1 \\
\hline 7 & EIE & 0 & 0 & 1 & 0 & 0 & 1 & 1 & 0 & 1 & 0 & 0 & 1 & 1 & 0 \\
\hline 8 & M\&A & 1 & 1 & 0 & 1 & 1 & 0 & 0 & 1 & 1 & 0 & 0 & 1 & 0 & 0 \\
\hline 9 & I\&PR & 0 & 0 & 1 & 0 & 0 & 0 & 0 & 0 & 1 & 0 & 0 & 1 & 1 & 0 \\
\hline 10 & GIL & 1 & 0 & 0 & 0 & 0 & 0 & 0 & 1 & 0 & 1 & 0 & 1 & 1 & 0 \\
\hline 11 & ECOM & 1 & 1 & 1 & 1 & 1 & 1 & 1 & 1 & 1 & 1 & 1 & 1 & 0 & 1 \\
\hline 12 & F\&T & 0 & 0 & 1 & 0 & 0 & 0 & 0 & 0 & 1 & 0 & 0 & 1 & 1 & 0 \\
\hline 13 & FR & 1 & 1 & 0 & 0 & 0 & 1 & 1 & 0 & 1 & 0 & 0 & 1 & 1 & 1 \\
\hline 14 & PDUM & 1 & 0 & 1 & 0 & 0 & 0 & 1 & 0 & 1 & 0 & 0 & 0 & 1 & 1 \\
\hline
\end{tabular}


Fig 3 : Final reachability matrix

\begin{tabular}{|c|c|c|c|c|c|c|c|c|c|c|c|c|c|c|c|c|}
\hline & Barr & 1 & 2 & 3 & 4 & 5 & 6 & 7 & 8 & 9 & 10 & 11 & 12 & 13 & 14 & D.P \\
\hline & & $\mathrm{RCC}$ & PAC & RTCB & SMA & SOOM & ELSC & EIE & M\&A & I\&PR & GIL & ECOM & $\mathrm{F} \& \mathrm{~T}$ & FR & $\overline{\text { PDUM }}$ & \\
\hline 1 & $\mathrm{RCC}$ & 1 & 0 & 1 & 0 & 0 & 1 & 1 & 0 & 1 & 0 & 0 & 1 & 1 & 1 & 8 \\
\hline 2 & PAC & 1 & 1 & 1 & 1 & 1 & 1 & 1 & 1 & 1 & 0 & 0 & 1 & 1 & 1 & 12 \\
\hline 3 & RTCB & 0 & 0 & 1 & 0 & 0 & 0 & 0 & 0 & 0 & 0 & 0 & 0 & 0 & 0 & 1 \\
\hline 4 & SMA & 1 & 1 & 1 & 1 & 1 & 1 & 1 & 1 & 1 & 0 & 0 & 1 & 1 & 1 & 12 \\
\hline 5 & SOOM & 1 & 1 & 1 & 1 & 1 & 1 & 1 & 1 & 1 & 0 & 0 & 1 & 1 & 1 & 12 \\
\hline 6 & ELSC & 1 & 0 & 1 & 0 & 0 & 1 & 1 & 0 & 1 & 0 & 0 & 1 & 1 & 1 & 7 \\
\hline 7 & EIE & 0 & 1 & 1 & 0 & 0 & 1 & 1 & 0 & 1 & 0 & 0 & 1 & 1 & 1 & 7 \\
\hline 8 & M\&A & 1 & 1 & 1 & 1 & 1 & 1 & 1 & 1 & 1 & 0 & 0 & 1 & 1 & 1 & 12 \\
\hline 9 & I\&PR & 1 & 1 & 1 & 0 & 0 & 1 & 1 & 0 & 1 & 0 & 0 & 1 & 1 & 1 & 8 \\
\hline 10 & GIL & 1 & 1 & 1 & 1 & 1 & 1 & 1 & 1 & 1 & 1 & 0 & 1 & 1 & 1 & 12 \\
\hline 11 & ECOM & 1 & 1 & 1 & 1 & 1 & 1 & 1 & 1 & 1 & 1 & 1 & 1 & 1 & 1 & 14 \\
\hline 12 & F\&T & 0 & 0 & 1 & 0 & 0 & 0 & 0 & 0 & 1 & 0 & 0 & 1 & 1 & 0 & 4 \\
\hline 13 & FR & 1 & 1 & 1 & 1 & 1 & 1 & 1 & 1 & 1 & 0 & 0 & 1 & 1 & 1 & 12 \\
\hline 14 & PDUM & 1 & 0 & 1 & 0 & 0 & 1 & 1 & 0 & 1 & 0 & 0 & 1 & 1 & 1 & 8 \\
\hline & De.P & 11 & 9 & 14 & 7 & 7 & 12 & 12 & 7 & 13 & 2 & 1 & 13 & 13 & 12 & \\
\hline
\end{tabular}

D.P : Driving power ; De.P : dependence power

Table 1 : Iteration I

\begin{tabular}{|c|c|c|c|}
\hline $\begin{array}{c}\text { Reachability } \\
\text { set }\end{array}$ & $\begin{array}{c}\text { Antecedent } \\
\text { set }\end{array}$ & $\begin{array}{c}\text { Intersection } \\
\text { set }\end{array}$ & $\begin{array}{c}\text { Iterati } \\
\text { on/ } \\
\text { Levels }\end{array}$ \\
\hline 3 & $\begin{array}{c}1,2,3,4,5,6,7,8,9, \\
10,11,12,13,14\end{array}$ & 3 & \\
\hline $3,9,12,13$ & $\begin{array}{l}1,2,4,5,6,7,8,9 \\
10,11,12,13,14\end{array}$ & $9,12,13$ & $\mathbf{I}$ \\
\hline $\begin{array}{c}3,6,7,912 \\
, 13,14\end{array}$ & $\begin{array}{c}1,2,4,5,6,7,8,9 \\
10,11,13,14\end{array}$ & $6,7,9,13,14$ & \\
\hline $\begin{array}{c}1,3,7,9,6,12 \\
13,14\end{array}$ & $\begin{array}{c}1,2,4,5,6,8,9,10 \\
11,13,14\end{array}$ & $\begin{array}{c}1,3,6,9,13 \\
14\end{array}$ & \\
\hline $\begin{array}{c}1,2,3,7,9,6,12 \\
13,14\end{array}$ & $2,4,5,8,9,10,11,3$ & $2,9,13$ & \\
\hline $\begin{array}{c}1,2,3,4,5,6,7,8 \\
, 9,12,13,14\end{array}$ & $2,4,5,8,10,11,3$ & $2,4,5,8,13$ & \\
\hline $\begin{array}{l}1,2,3,4,5,6,7,8 \\
, 9,10,12,13,14\end{array}$ & 10,11 & 10,11 & \\
\hline $\begin{array}{c}1,2,3,4,5,6,7,8 \\
, 9,10,11,12,13 \\
, 14\end{array}$ & 11 & 11 & \\
\hline
\end{tabular}


Table3:IterationIII

\begin{tabular}{|c|c|c|}
\hline Reachability set & Antecedent set & Intersection set \\
\hline $\mathbf{9 , 1 2 , 1 3}$ & $1,2,4,5,6,7,8,9$, & $\mathbf{9 , 1 2 , 1 3}$ \\
& $10,11,12,13,14$ & $6,7,9,13,14$ \\
\hline $6,7,912,13,14$ & $1,2,4,5,6,7,8,9$, & $1,3,6,9,13$, \\
& $10,11,13,14$ & 14 \\
\hline $1,7,9,6,12,13,14$ & $1,2,4,5,6,8,9,10,11,13,14$ & $2,9,13$ \\
\hline $1,2,7,9,6,12,13,14$ & & $2,4,5,8,13$ \\
\hline $1,2,4,5,6,7,8,9,12,13,14$ & $2,4,5,8,9,10,11,13$ & 10,11 \\
\hline
\end{tabular}

Table 2 : Iteration II

\begin{tabular}{|c|c|c|c|}
\hline $\begin{array}{c}\text { Reachability } \\
\text { set }\end{array}$ & Antecedent set & $\begin{array}{c}\text { Intersectio } \\
\text { n set }\end{array}$ & $\begin{array}{c}\text { Iterat } \\
\text { ion }\end{array}$ \\
\hline $6,7,14$ & $\begin{array}{c}1,2,4,5,6,7,8 \\
10,11,14\end{array}$ & $6,7,14$ & \multirow{6}{*}{ III } \\
\hline $1,7,6,14$ & $\begin{array}{c}1,2,4,5,6,8,10 \\
11,14\end{array}$ & $1,3,6,14$ & \\
\hline $1,2,7,6,14$ & $2,4,5,8,10,11,13$ & 2 , & \\
\hline $\begin{array}{c}1,2,4,5,6,7,8 \\
14\end{array}$ & $2,4,5,8,10,11,13$ & $2,4,5,8$ & \\
\hline $\begin{array}{c}1,2,4,5,6,7,8,1 \\
0,14\end{array}$ & 10,11 & 10,11 & \\
\hline $\begin{array}{c}1,2,4,5,6,7,8,1 \\
0,11,14\end{array}$ & 11 & 11 & \\
\hline
\end{tabular}

Table 4 : Iteration IV

\begin{tabular}{|c|c|c|c|}
\hline $\begin{array}{c}\text { Reachability } \\
\text { set }\end{array}$ & Antecedent set & $\begin{array}{c}\text { Intersecti } \\
\text { on set }\end{array}$ & $\begin{array}{c}\text { Iteration/ } \\
\text { Levels }\end{array}$ \\
\hline $\mathbf{1}$ & $\begin{array}{c}1,2,4,5,8,9,10, \\
11,13\end{array}$ & 1 & \multirow{2}{*}{ IV } \\
\hline 1,2 & $2,4,5,8,9$, & 2, & \\
\hline $1,2,4,5,8$ & $10,11,13$ & & \\
\hline $1,2,4,5,8,9,10$, & 10,11 & 10,11 & \\
12,13 & & & \\
\hline $1,2,4,5,8,9,10$, & 11 & 11 & \\
$11,12,13$ & & & \\
\hline
\end{tabular}

Table 5 : Iteration V

\begin{tabular}{|c|c|c|c|}
\hline $\begin{array}{c}\text { Reachability } \\
\text { set }\end{array}$ & Antecedent set & $\begin{array}{c}\text { Intersection } \\
\text { set }\end{array}$ & $\begin{array}{c}\text { Itera } \\
\text { tion }\end{array}$ \\
\hline $\mathbf{2}$ & $2,4,5,8,10,11$ & $\mathbf{2}$ & \\
\cline { 1 - 3 } $2,4,5,8$ & $2,4,5,8,10,11$ & $2,4,5,8$ & \multirow{2}{*}{$\mathbf{V}$} \\
\hline $2,4,5,8,10$ & 10,11 & 10,11 & \\
\hline $2,4,5,8,10,11$ & 11 & 11 & \\
\hline
\end{tabular}

Table 6 : Iteration VI

\begin{tabular}{|c|c|c|c|}
\hline $\begin{array}{c}\text { Reachability } \\
\text { set }\end{array}$ & Antecedent set & $\begin{array}{c}\text { Intersection } \\
\text { set }\end{array}$ & $\begin{array}{c}\text { Itera } \\
\text { tion }\end{array}$ \\
\cline { 1 - 3 } $\mathbf{4 , 5 , 8}$ & $4,5,8,10,11$ & $\mathbf{4 , 5 , 8}$ & \multirow{2}{*}{ VI } \\
\cline { 1 - 3 } $4,5,8,10$ & 10,11 & 10,11 & \\
\hline $4,5,8,10,11$ & 11 & 11 & \\
\hline
\end{tabular}

Table 7 : Iteration VII

\begin{tabular}{|c|c|c|c|}
\hline $\begin{array}{c}\text { Reachability } \\
\text { set }\end{array}$ & $\begin{array}{c}\text { Antecedent } \\
\text { set }\end{array}$ & $\begin{array}{c}\text { Intersection } \\
\text { set }\end{array}$ & $\begin{array}{c}\text { Itera } \\
\text { tion }\end{array}$ \\
\cline { 1 - 3 } $\mathbf{1 0}$ & 10,11 & 10,11 & \\
& 11 & 11 & VII \\
\hline
\end{tabular}

Table 8 : Iteration VIII

\begin{tabular}{|c|c|c|c|}
\hline $\begin{array}{c}\text { Reachability } \\
\text { set }\end{array}$ & $\begin{array}{c}\text { Antecedent } \\
\text { set }\end{array}$ & $\begin{array}{c}\text { Intersection } \\
\text { set }\end{array}$ & $\begin{array}{c}\text { Itera } \\
\text { tion }\end{array}$ \\
\hline 11 & 11 & 11 & VIII \\
\hline
\end{tabular}

\subsection{Classification of factors}

The critical success factors described earlier are classified in to four clusters viz. autonomous factor, dependent factors, linkage factors and independent factors are mentioned below. 
Fig . 4: Driving power and dependence diagram

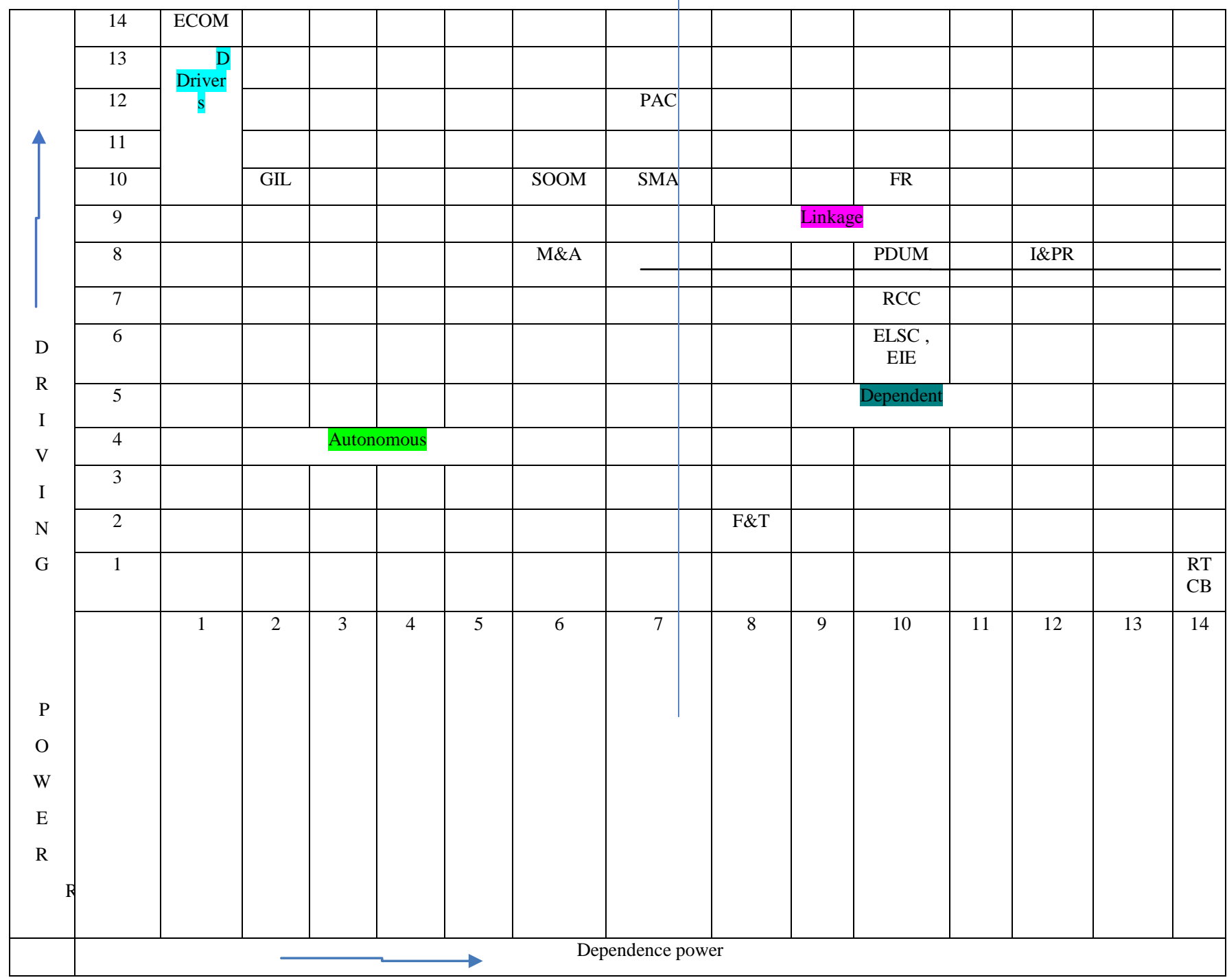

\section{FUTURE DIRECTIONS}

Present research work applies the MCDM technique of Interpretive structural modelling methodology (ISM) to establish the hierarchical relationships amongst the various success factors and challenges for the growth of lingerie industry in developing country such as India. Researchers may make use of other techniques such as DEMATEL, AHP or hybrid techniques such as fuzzy AHP , AHP-ISM etc. to extend the research further .

\section{MANAGERIAL IMPLICATIONS}

- The success of the global intimate apparel market lies in understanding the right trend, deciding the appropriate time of launch, and selecting the right distribution store. Specialist lingerie retailers should keep in mind the price band and the average sales cycle of intimate apparel before deciding the restock rate of any intimate apparel.

- By selecting the appropriate restock rate, the specialist lingerie retailers can manage their supply chain logistics in a better manner. Worldwide Market Growth Forecast of LingerieToday, the main concern about marketing the lingerie products is the fight for share between global brands and retailers' local labels worldwide.

- It is also about consumers' choice and acceptance of brand. With its matchless combination of fashion and function, lingerie is a product category that crosses the fine line between necessity and luxury.

- To know the global lingerie market, it is essential to check out not only the competition between brands, but also the separate lingerie wars taking place between brands and local retail labels.

\section{REFERENCES}

[1] www.yotpo.com/log/2016/04/19/fashion-idustrycustomer-reviews-data/

[2] https://www.entrepreneur.com/article/275419

[3] Warfield, J.N. 1974. Developing interconnection matrices in structural modeling. Proceedings of IEEE Transactions on System, Man, and Cybernetics, SMC, 4 (1), 81-87. 